\title{
NOTE
}

\section{Consumption of silicic acid below the euphotic zone by sedimenting diatom blooms in the Barents Sea}

\author{
Francisco Rey \& Hein Rune Skjoldal
}

Institute of Marine Research, Directorate of Fisheries, PO Box 1870, N-5011 Bergen-Nordnes, Norway

\begin{abstract}
Massive sedimentation of spring phytoplankton blooms occurs in the Barents Sea as in many other shelf sea environments. Associated with this sedimentation there is a large decrease in concentration of dissolved silicic acid below the nitracline. This decrease is apparently related to resting spore formation of the dominant diatom species Chaetoceros socialis. The deep silicic acid consumption seems to be a regular and extensive phenomenon which results in a vertical separation of the silicic acid gradient from the nitracline. This will disfavour further growth of diatoms during the summer season due to reduced upward transport of silicic acid by vertical mixing.
\end{abstract}

Extensive sedimentation of organic material following phytoplankton blooms has been documented for both coastal and oceanic environments (Smetacek 1980, Bodungen et al. 1981, Peinert et al. 1982, Billett et al. 1983, Wassmann 1983, 1985, Davies \& Payne 1984, Schnack et al. 1985). Diatoms are typically the bloom organisms and their sedimentation has great ecological consequences for both zooplankton and benthos (Walsh 1983, Smetacek 1984, 1985). Increased sinking rate due to nutrient limitation is probably involved (Bienfang et al. 1982, Bienfang \& Harrison 1984), although mass sedimentation has been suggested to represent a seeding stage in the life cycle of bloom diatoms (Smetacek 1985). We present here field evidence for a large decrease in concentration of dissolved silicic acid below the euphotic zone associated with sedimentation of diatom blooms in the Barents Sea. This appears to be a regular and large-scale phenomenon which could be of great importance for the ecology in this sea area.

The Institute of Marine Research, Bergen, Norway, has since 1979 conducted biological oceanographical investigations in the Barents Sea with the aim of describing the feeding conditions of capelin Mallotus villosus. Our study area has mainly been the western and central part between $74^{\circ}$ and $78^{\circ} \mathrm{N}$, but since 1984 this was extended to include also the eastern part (Fig. 1).

Compared to other polar seas the Barents Sea is relatively poor in dissolved nutrients, particularly silicic acid (Sakshaug \& Holm-Hansen 1984). During summer, the ice retreats ca $500 \mathrm{~km}$ northwards (Loeng 1979). A diatom bloom is associated with the retreating ice-edge and this causes depletion of silicic acid and nitrate from the upper water layer (Rey \& Loeng 1985). Towards the end of the bloom, the nitracline is usually located around $40 \mathrm{~m}$ and deeper than the pycnocline (Rey \& Loeng 1985).

This is exemplified in Fig. 2 which shows vertical profiles from a station sampled at a late phase of the phytoplankton spring bloom in the central Barents Sea (Fig. 1). Sampling and analytical procedures were as described by Rey \& Loeng (1985) and Skjoldal \& Wassmann (1986). A marked pycnocline at 25 to $30 \mathrm{~m}$ sepa-

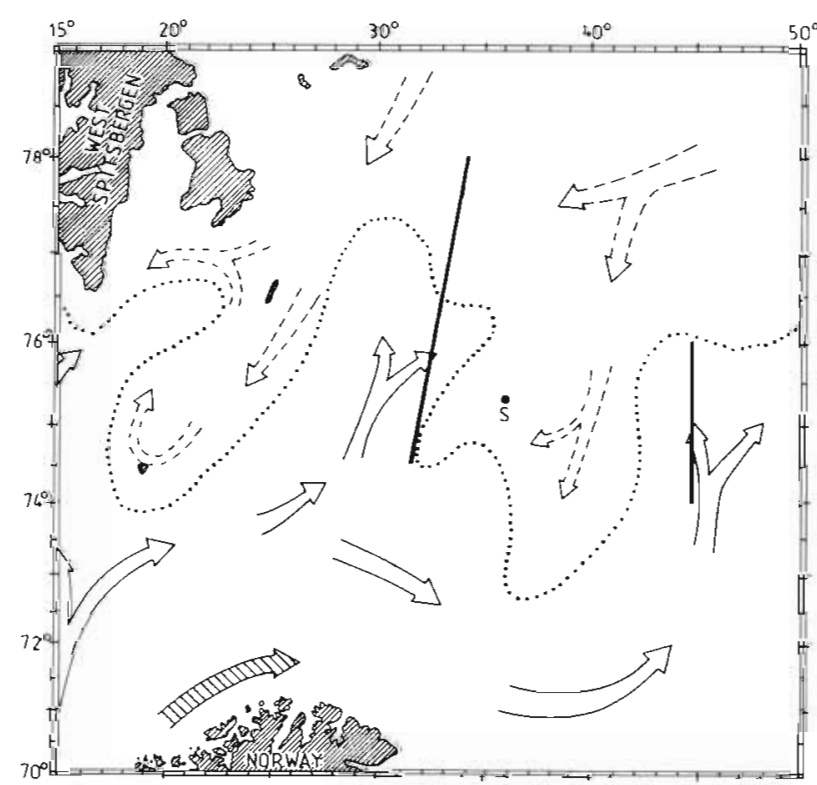

Fig. 1. Map of the Barents Sea showing the positions of the central and eastern transects (heavy lines) and Stn 713 (S), and a simplified current pattern (open arrows: Atlantic water; broken arrows: Arctic water; hatched arrow: coastal water). Dotted line: approximate position of the polar front 
rated a top layer of slightly warmed meltwater from the core of cold Arctic water below (Fig. 2B). Nitrate and phosphate showed marked gradients between 45 and $60 \mathrm{~m}$. Silicic acid, on the other hand, was depleted down to $75 \mathrm{~m}$, with a marked gradient below (Fig. 2A). Ammonium exhibited a peak of $1.1 \mu \mathrm{M}$ in the lower part of the nitracline at $60 \mathrm{~m}$ (Fig. 2A).

Chlorophyll in vivo fluorescence (Fig. 2C) showed a maximum at the top of the nitracline $(45 \mathrm{~m})$ where POC and PON also had their maxima (Fig. 2D). The highest chlorophyll a concentrations were found deeper (60 to $75 \mathrm{~m}$ ), but this probably reflected an increase in chlorophyll due to photoadaptation (Bienfang et al. 1983) rather than a maximum in phytoplankton biomass. Particulate silicon increased steadily with depth to $1.5 \mu \mathrm{M}$ at $100 \mathrm{~m}$ (Fig. 2D). The content of particulate silicon was low compared to the amount of dissolved silicic acid depleted between 45 and $75 \mathrm{~m}$. We therefore conclude that the majority of diatoms, which we suggest are responsible for this depletion, had already sedimented out from the investigated part of the water column. Species-specific differences in sinking rate (Malone et al. 1983) or seeding of resting stages
(Smetacek 1985) are possible mechanisms behind such a sink-out.

Massive reduction of the silicic acid content below the nitracline is not an isolated phenomenon, but has been observed regularly over extensive areas of the Barents Sea. Fig. 3 shows isopleth diagrams of silicic acid concentrations in summer along a north-south section in the central Barents Sea (Fig. 1). Isolines for 1 and $8 \mu \mathrm{M}$ nitrate are shown superimposed on these isopleths. The June 1983 section extended $130 \mathrm{~km}$ into ice-covered waters where a pre-bloom plankton situation occurred. Silicic acid (about $4 \mu \mathrm{M}$ ) and nitrate (about $8 \mu \mathrm{M}$ ) occurred here in the typical 1:2 molar ratio (Ellertsen et al. 1982, Sakshaug \& Holm-Hansen 1984). South of $77^{\circ} \mathrm{N}$, however, nutrients were virtually depleted from the surface layer and silicic acid concentrations at the depth of $8 \mu \mathrm{M} \mathrm{NO}_{3}$ were from 1 to $3 \mu \mathrm{M}$ (Fig. 3A). Similarly, low silicic acid concentrations were found at the $8 \mu \mathrm{M}$ nitrate depth in June 1984 both along the central section (Fig. 3B) and a section along $45^{\circ} \mathrm{E}$. A plot of silicic acid vs nitrate concentrations for sampling depths of $50 \mathrm{~m}$ and deeper from this eastern section reveals that the majority of samples from all

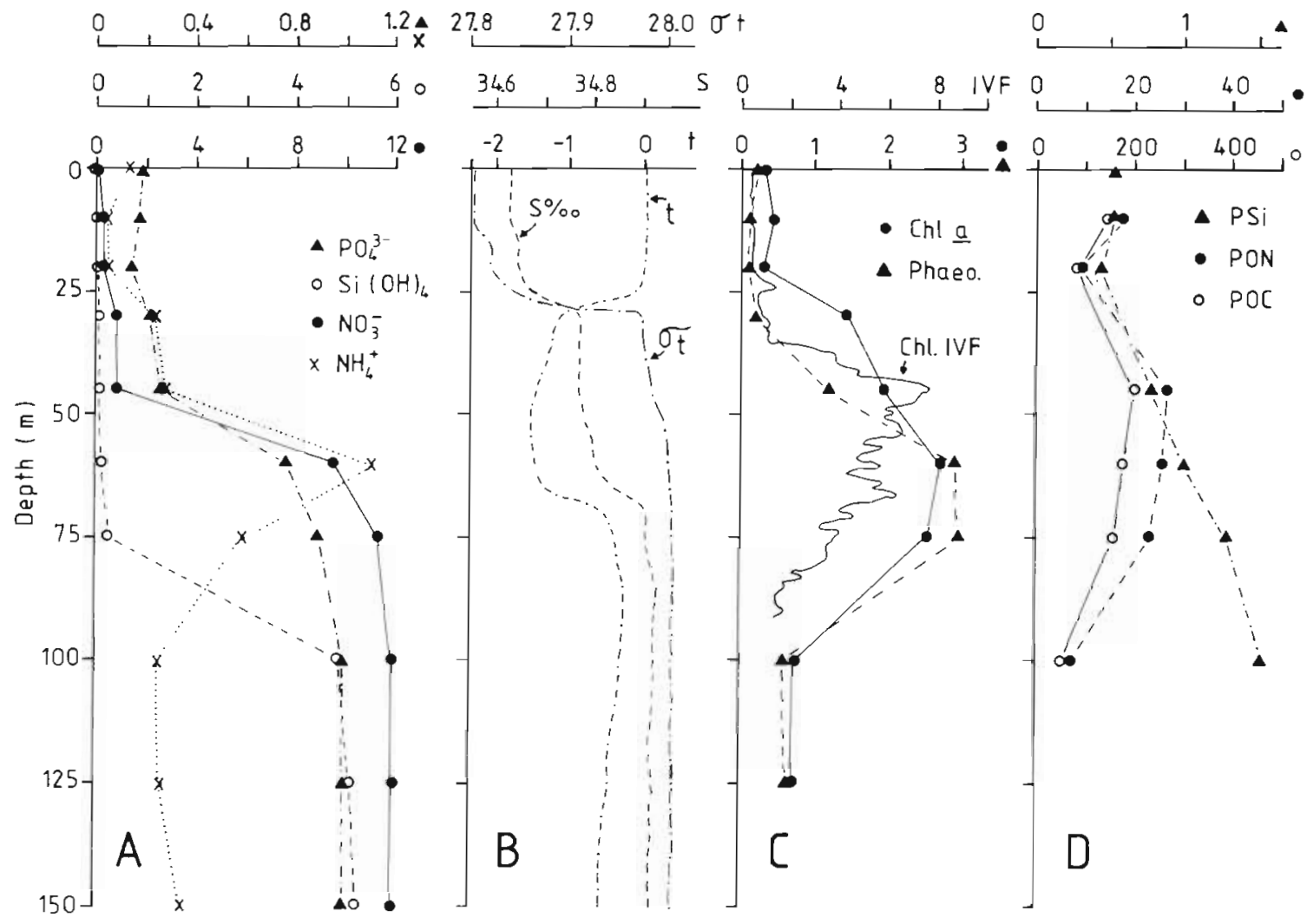

Fig. 2. Vertical structure of physical, chemical and biological properties of the water column at a station sampled at a late phase of the spring bloom in the Barents Sea $\left(75^{\circ} 20^{\prime} \mathrm{N}, 36^{\circ} 00^{\prime} \mathrm{E}\right.$ : R/V G. O. Sars, Stn $\left.713_{i} 7 \mathrm{Jun} 1984\right)$. (A) Concentrations of nitrate, phosphate, silicic acid and ammonium $(\mu \mathrm{M})$. (B) Temperature $\left({ }^{\circ} \mathrm{C}\right)$, salinity $(\%)$ and water density $\left(\sigma_{1}\right)$. (C) Chlorophyll a, phaeopigments $\left(\mathrm{mg} \mathrm{m}^{-3}\right)$, and chlorophyll in vivo fluorescence measured in situ (IVF; relative units). (D) Particulate organic carbon (POC), organic nitrogen (PON) $\left(\mathrm{mg} \mathrm{m}^{-3}\right)$ and biogenic silicon (PSi) $(\mu \mathrm{M})$ 
stations north of $74^{\circ} 30^{\prime} \mathrm{N}$ were poor in silicic acid relative to nitrate (Fig. 4).

Positioning of the silicic acid gradient deeper than the nitracline has been reported for only a few other environments, e.g. a land-locked fjord in Norway (Skjoldal \& Wassmann 1986) and subtropical water off Hawaii (Bienfang et al. 1984). For the world oceans there seems to be great variation with respect to nitrate
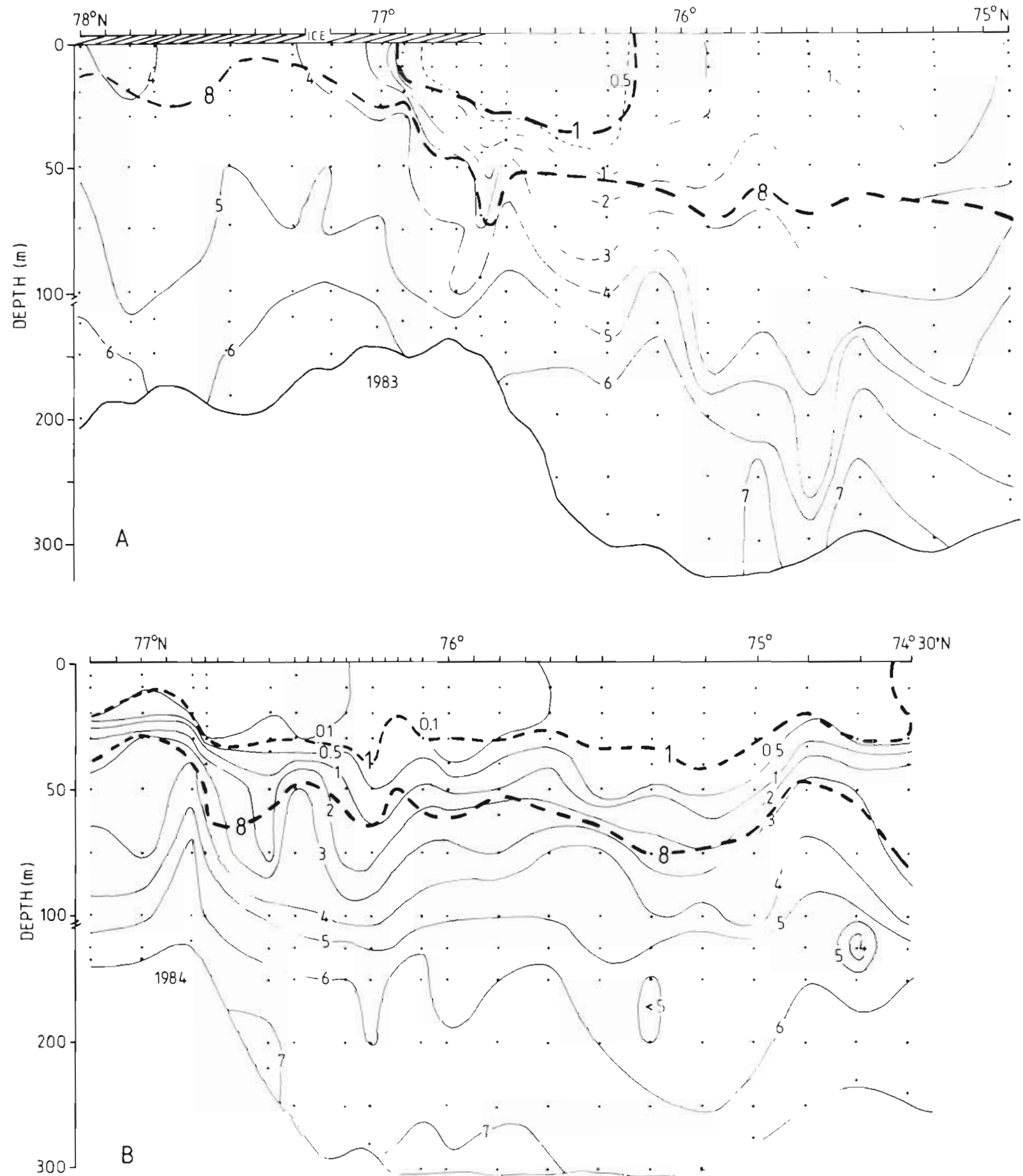

Fig. 3. Isopleth diagrams of the distribution of silicic acid along a section in the central Barents Sea. Superimposed are the $1 \mu M$ and $8 \mu \mathrm{M}$ isolines for nitrate (thick, broken lines). (A) Section extending from $75^{\circ} 00^{\prime} \mathrm{N}, 31^{\circ} 50^{\prime} \mathrm{E}$ to $78^{\circ} 04^{\prime} \mathrm{N}, 34^{\circ} 26^{\prime} \mathrm{E}$, covered on 4 to 8 Jun 1983 during cruise with M/S Lance. (B) Section extending from $74^{\circ} 30^{\prime} \mathrm{N}, 31^{\circ} 29^{\prime} \mathrm{E}$ to $77^{\circ} 10^{\prime} \mathrm{N}, 33^{\circ} 29^{\prime} \mathrm{E}$, covered on 3 to 6 Jun 1984 during cruise with R/V G. O. Sars 
vs silicic acid depletion, certain regions being characterized by nitrate excess and others by silicic acid excess (Kamykowski \& Zentara 1985).

Nitrogen recycling can influence the phytoplankton consumption ratio of nitrate to silicic acid (Kamykowski \& Zentara 1985). Utilization of recycled ammonium in the absence of any substantial remineralization of Si may have contributed to the discrepancy in the silicic acid vs nitrate depletion relation below the nitracline. The elevated ammonium concentrations in this depth interval (Fig. 2A) suggest that nitrogen remineralization occurred. We consider, however, that any such influence was of limited magnitude. Concentrations of nitrate and silicic acid below their respective gradients were typical for winter nutrient levels (Hassel et al. 1986). Spring bloom development in melt-water regions is a fairly rapid process (Rey \& Loeng 1985, Slagstad 1985), as is also generally the sedimentation of spring diatom blooms following nutrient depletion (Smetacek 1984, 1985).

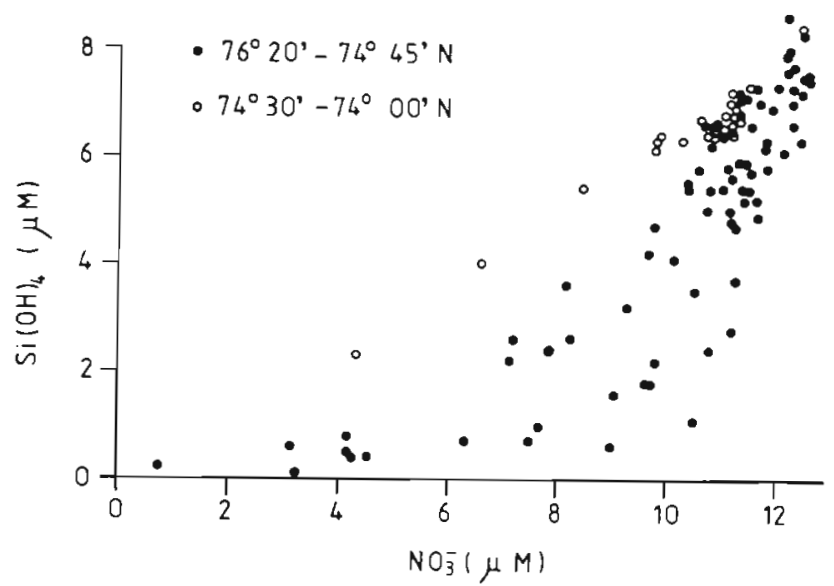

Fig. 4. Relation between concentrations of silicic acid and nitrate in samples from $50 \mathrm{~m}$ and deeper at stations from a section extending from $74^{\circ} 00^{\prime} \mathrm{N}$ to $76^{\circ} 20^{\prime} \mathrm{N}$ along $45^{\circ} \mathrm{E}$, covered on 10 to 12 Jun 1984 with R/V G. O. Sars
Substantial reutilization of remineralized $\mathrm{N}$ in the deeper part of the euphotic zone towards the end of the bloom is therefore unlikely (cf. Lännergren \& Skjoldal 1976, Pomeroy \& Deibel 1986).

Horizontal advection is another factor that can influence the pattern of vertical nutrient distributions by disrupting the vertical continuity of properties and processes. The uniform pattern of vertical distributions of nitrate and silicic acid over vast areas of the Barents Sea (Fig. 3) suggests, however, that advection did not play a major role in this respect.

The diatom Chaetoceros socialis, which together with the colony-forming flagellate Phaeocystis pouchetii is usually the dominant component of the ice-edge bloom (Rey \& Loeng 1985), occurred at 1 to 4 $\times 10^{6}$ cells $^{-1}$ from 45 to $100 \mathrm{~m}$ at $\operatorname{Stn} 713$ (Table 1 ). There was a dramatic increase in the proportion of resting spores of $C$. socialis (as identified by light microscopy), from none at $60 \mathrm{~m}$ to $100 \%$ at $100 \mathrm{~m}$. It appears therefore that formation of resting spores took place at the top of the silicic acid gradient (Fig. 2A) and that these spores subsequently sedimented out. Spores of $C$. socialis have been shown to sink about 5 times as fast as vegetative cells (Bienfang 1981) and their formation seems to be triggered by nutrient limitation (Davis et al. 1980).

Uptake of silicic acid in diatoms is usually a rapid process, restricted to the stage in the cell cycle where cell division occurs (Darley 1974, Paasche 1980, Sullivan \& Volcani 1981). More than $90 \%$ of the silicic acid taken up is immediately deposited at the cell walls, the rest being probably accumulated for use in metabolic processes (Paasche 1980, Sullivan \& Volcani 1981). The silicification process requires little energy compared to total cellular energy needs (Raven 1983).

Much of the phytoplankton biomass in the late bloom situation was found below the euphotic zone $(1 \%$ light level at about $50 \mathrm{~m}$ ) (Fig. 2C). The algae were apparently adapted to low light levels, as indi-

Table 1. Cell numbers of dominant species, light-saturated rate of photosynthesis, and chemical ratios for phytoplankton and seston in and below the euphotic zone at Stn 713 (see Fig. 2)

\begin{tabular}{|c|c|c|c|c|c|}
\hline \multirow[t]{2}{*}{ Variable } & \multicolumn{5}{|c|}{ Depth } \\
\hline & $10 \mathrm{~m}$ & $45 \mathrm{~m}$ & $60 \mathrm{~m}$ & $75 \mathrm{~m}$ & $100 \mathrm{~m}$ \\
\hline Phaeocystis pouchetii (cells $1^{-1}$ ) & $4.0 \times 10^{4}$ & $3.9 \times 10^{6}$ & $4.1 \times 10^{6}$ & $2.9 \times 10^{6}$ & $1.2 \times 10^{5}$ \\
\hline Chaetoceros socialis (cells $1^{-1}$ ) & $5.1 \times 10^{4}$ & $1.1 \times 10^{6}$ & $2.0 \times 10^{6}$ & $3.7 \times 10^{6}$ & $8.3 \times 10^{5}$ \\
\hline C. socialis, resting spores $(\%)$ & 78 & 2 & 0 & 76 & 100 \\
\hline $\mathrm{C}$ assimilation ( $\mathrm{gg} \mathrm{Cl}^{-1} \mathrm{~h}^{-1}$ ) & 0.42 & 0.96 & 1.46 & 3.97 & - \\
\hline 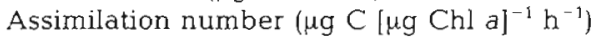 & 0.98 & 0.56 & 0.54 & 1.58 & - \\
\hline $\mathrm{Chl} a / \mathrm{C}(w / w)$ & 0.0032 & 0.0087 & 0.0155 & 0.0161 & 0.0135 \\
\hline N/C (atomic ratio) & 0.112 & 0.115 & 0.127 & 0.127 & 0.118 \\
\hline N/P (atomic ratio) & 23.3 & 29.1 & 21.8 & 28.6 & 16.7 \\
\hline Si/C (atomic ratio) & 0.047 & 0.047 & 0.069 & 0.096 & 0.338 \\
\hline
\end{tabular}


cated by high chlorophyll a/C ratios at 60 and $75 \mathrm{~m}$ (Table 1). The phytoplankton at $75 \mathrm{~m}$, with a high proportion of Chaetoceros socialis resting spores, showed higher capacity for light-saturated photosynthesis than the phytoplankton higher up in the water column (Table 1). The N/C and N/P atomic ratios of the particulate material showed little variation with depth, whereas the $\mathrm{Si} / \mathrm{C}$ ratio increased with depth below $45 \mathrm{~m}$ (Table 1). This reflected the increasing dominance of $C$. socialis with depth, but probably also a higher silicon content per cell. Thus the $\mathrm{Si} / \mathrm{C}$ ratio at $100 \mathrm{~m}(0.34)$ falls in the upper range of values reported for marine diatoms (Brzezinski 1985).

These results indicate that heavily silicified resting spores can have an important role in the life cycle and survival strategy of at least one centric diatom species in the Barents Sea. Resting spores appear to be specialized to persist in darkness or low light, and show high photosynthetic ability coupled with low rates of respiration (Hargraves \& French 1983).

The fact that Chaetoceros socialis, a small diatom of about 7 to $8 \mu \mathrm{m}$ in diameter, seems to be the main species responsible for the depletion of silicic acid in the Barents Sea is important in the light of other investigations which have shown small Chaetoceros species growing at very low silicic acid concentrations (Hargraves \& French 1983). Silicic acid deprivation has been found to elicit the greatest sinking response in diatom populations (Bienfang et al. 1982, Bienfang \& Harrison 1984), and it has been suggested that silica can act as a sinking device, its effect being relatively greater in small cells with their inherently slower sinking speeds (Walsby \& Reynolds 1980). The apparently high consumption of silicic acid below the euphotic zone and the formation of resting spores are probably integrated parts of a survival strategy for $C$. socialis. It is interesting to note that the majority of the dominant diatom species in the Barents Sea are of the restingspore-forming type. On the other hand, the typical forms with resting cells, such as Skeletonema costatum, are seldom found.

The marked consumption of silicic acid below the euphotic zone has consequences for the further development of phytoplankton during the summer. Melt-water and warming of the surface layer lead to a fairly stable upper water column over vast areas of the northern Barents Sea (Rey \& Loeng 1985). The positioning of the silicic acid gradient well below the nitracline will inevitably result in proportionally less upwards transport of silicic acid than of nitrate and phosphate into the lower part of the euphotic zone by mixing processes. This will disfavour the growth of diatoms during the summer season.

Acknowledgements. This work was supported by the Norwegian Fisheries Research Council (Project No. I 701.106) and is a contribution from the Norwegian Research Program for Marine Arctic Ecology (PRO MARE). We thank M. Hagebor for analyses of nutrients and particulate silicon

\section{LITERATURE CITED}

Bienfang, P. K. (1981). Sinking rates of heterogeneous, temperate phytoplankton populations. J. Plankton Res. 3: 235-253

Bienfang, P. K., Harrison, P. J. (1984). Sinking-rate response of natural assemblages of temperate and subtropical phytoplankton to nutrient depletion. Mar. Biol. 83: 293-300

Bienfang, P. K., Harrison, P. J., Quarmby, L. M. (1982). Sinking rate response to depletion of nitrate, phosphate and silicate in four marine diatoms. Mar. Biol. 67: 295-302

Bienfang, P., Szyper, J., Laws, E. (1983). Sinking rate and pigment responses to light-limitation of a marine diatom: implications to dynamics of chlorophyll maximum layers. Oceanologica Acta 6: 55-62

Bienfang, P. K., Szyper, J. P., Okamoto, M. Y., Noda, E. K. (1984). Temporal and spatial variability of phytoplankton in a subtropical ecosystem. Limnol. Oceanogr. 29: 527-539

Billett, D. S. M., Lampitt, R. S., Rice, A. L., Mantoura, R. F. C. (1983). Seasonal sedimentation of phytoplankton to the deep-sea benthos. Nature, Lond. 302: 520-522

Bodungen, B. v., Bröckel, K. v., Smetacek, V., Zeitzschel, B. (1981). Growth and sedimentation of the phytoplankton spring bloom in the Bornholm Sea (Baltic Sea). Kieler Meeresforsch. (Sonderh.) 5: 49-60

Brzezinski, M. A. (1985). The Si : C:N ratio of marine diatoms: interspecific variability and the effect of some environmental variables. J. Phycol. 21: 347-357

Darley, W. M. (1974). Silicification and calcification. In Stewart, W. D. P. (ed.) Algal physiology and biochemistry. Blackwell, Oxford, p. 655-675

Davies, J. M., Payne, R. (1984). Supply of organic matter to the sediment in the northern North Sea during a spring phytoplankton bloom. Mar. Biol. 78: 315-324

Davis, C. O., Hollibaugh, J. T., Seibert, D. L. R., Thomas, W. H. (1980). Formation of resting spores by Leptocylindrus danicus (Bacillariophyceae) in a controlled experimental ecosystem. J. Phycol. 16; 296-302

Ellertsen, B., Hassel, A., Loeng, H., Rey, F., Tjelmeland, S., Slagstad, D. (1982). Økologiske undersøkelser nær iskanten i Barentshavet somrene 1979 og 1980 (Ecological investigations in the marginal ice zone in the Barents Sea the summers 1979 and 1980). Fisken Hav. (1982) No. 3: $31-83$

Hargraves, P. E., French, F. W. (1983). Diatom resting spores: significance and strategies. In: Fryxell, G. A. (ed.) Survival strategies of the algae. Cambridge University Press, Cambridge, p. $49-68$

Hassel, A., Loeng, H., Skjoldal, H. R. (1986). Marinøkologiske undersøkelser i Barentshavet i januar 1985. Institute of Marine Research Rep. No. FO 8604, Bergen

Kamykowski, D., Zentara, S.-J. (1985). Nitrate and silicic acid in the world ocean: patterns and processes. Mar. Ecol. Prog. Ser, 26: 47-59

Lännergren, C., Skjoldal, H. R. (1976). The spring phytoplankton bloom in Lindåspollene, a land-locked Norwegian fjord. Autotrophic and heterotrophic activities in relation to nutrients. In: Persoone, G., Jaspers, E. (ed.) Proceedings of the 10th European Marine Biology Symposium, Vol. 2. Universa Press, Wetteren, p. 363-391

Loeng, H. (1979). Isforholdene i Barentshavet og vest av 
Spitsbergen. En oversikt (A review of the sea ice conditions of the Barents Sea and the area west of Spitsbergen). Fisken Hav. (1979) No. 2: 29-75

Malone, T. C., Falkowski, P. G., Hopkins, T. S., Rowe, G. T., Whitledge, T. E. (1983). Mesoscale response of diatom populations to a wind event in the plume of the Hudson River. Deep Sea Res. 30A: 149-170

Paasche, E. (1980). Silicon. In: Morris, I. (ed.) The physiological ecology of phytoplankton. Blackwell, Oxford p. $259-284$

Peinert, R., Saure, A., Stegmann, P., Stienen, C., Haardt, H., Smetacek, V. (1982). Dynamics of primary production and sedimentation in a coastal ecosystem. Neth. J. Sea Res. 16: $276-289$

Pomeroy, L. R., Deibel, D. (1986). Temperature Iegulation of bacterial activity during the spring bloom in Newfoundland coastal waters. Science 233: 359-361

Raven, J. A. (1983). The transport and function of silicon in plants. Biol. Rev. 58: 179-207

Rey, F., Loeng, H. (1985). The influence of ice and hydrographic conditions on the development of phytoplankton in the Barents Sea. In: Gray, J. S., Christiansen, M. E. (ed.) Manne biology of polar regions and effects of stress on marine organisms. Wiley, Chichester, p. 49-63

Sakshaug, E., Holm-Hansen, 'O. (1984). Factors governing pelagic production in polar oceans. In: Holm-Hansen, $\mathrm{O}$., Bolis, L., Gilles, R. (ed.) Marine phytoplankton and productivity. Springer, Berlin, p. 1-18

Schnack, S. B., Smetacek, V., Bodungen, B. v., Stegmann, P. (1985). Utilization of phytoplankton by copepods in Antarctic waters during spring. In: Gray, J. S., Christiansen, M. E. (ed.) Marine biology of polar regions and effects of stress on marine organisms. Wiley, Chichester, p. 65-81
Skjoldal, H. R., Wassmann, P. (1986). Sedimentation of particulate organic matter and silicium during spring and summer in Lindåspollene, western Norway. Mar. Ecol. Prog. Ser. 30: 49-63

Slagstad, D. (1985). A model of phytoplankton in the marginal sea-ice zone of the Barents Sea. In: Gray, J. S., Christiansen, M. E. (ed.) Marine biology of polar regions and effects of stress on marine organisms. Wiley, Chichester, p. 35-48

Smetacek, V. (1980). Annual cycle of sedimentation in relation to plankton ecology in western Kiel Bight. Ophelia, Suppl. 1: 65-76

Smetacek, V. (1984). The supply of food to the benthos. In: Fasham, M. J. (ed.) Flows of energy and materials in marine ecosystems: theory and practice. Plenum Press, New York, p. 517-547

Smetacek, V. (1985). Role of sinking in diatom life-history cycles: ecological, evolutionary and geological significance. Mar. Biol. 84: 239-251

Sullivan, C. W., Volcani, B. E. (1981). Silicon in the cellular metabolism of diatoms. In: Simpson, T. L., Volcani, B. E. (ed.) Silicon and siliceous structures in biological systems. Springer-Verlag, New York, p. 15-42

Walsby, A. E., Reynolds, C. S. (1980). Sinking and floating. In: Morris, I. (ed.) The physiological ecology of phytoplankton. Blackwell, Oxford, p. 371-412

Walsh, J. J. (1983). Death in the sea: enigmatic phytoplankton losses. Prog. Oceanogr. 12:1-86

Wassmann, P. (1983). Sedimentation of organic and inorganic particulate material in Lindasspollene, a stratified, landlocked fjord in western Norway. Mar. Ecol. Prog. Ser. 13: $237-248$

Wassmann, P. (1985). Sedimentation of particulate material in Nordåsvannet, a hypertrophic, land-locked fjord in western Norway. Mar. Ecol. Prog. Ser. 22: 259-271 